\title{
REPUTASI MEREK, KOMPETENSI MEREK, KESUKAAN MEREK DAN KEPERCAYAAN PADA PERUSAHAAN TERHADAP LOYALITAS MEREK APOTEK VITKA FARMA
}

\author{
Dewi Aurora Mikasari ${ }^{1}$ Agung Edy Wibowo ${ }^{2}$ \\ ${ }^{1}$ Prodi, Manajemen Tata Hidang, Batam Tourism Polytechnic, Batam \\ ${ }^{2}$ Prodi Perencanaan dan Pengembangan Pariwisata, Batam Tourism Polytechnic, Batam \\ e-mail: aurora@btp.ac.id, agungedy@btp.ac.id
}

\begin{abstract}
As a business entity, pharmaceutical companies have a big part in providing a contribution to the growth of a nation; the number of pharmaceutical retail outlets support the strength of a country health system. Apotek Vitka Farma is one of the pharmacies that are existing and provide support to the particular vision. As a business entity Apotek Vitka Farma has a compound competition space with other retails in similar industries. The expectation of winning over potential niche existing customers is a priority in such intense competition. The significant part of the whole process is to change the behavior of consumers in the end to become loyal customers. This research aims to obtain outcomes on the analysis of brand reputation variable, brand competence, brand preferences and consumer's trust in the company to the loyalty in the brand of Apotek Vitka Farma.The survey with purposive sampling method was used in this study with a sample number of 120 respondents. Classic assumption tests were used to ensure that the Best Linear Unbiased Estimator (BLUE) requirements were met before further testing using multiple linear regression analysis. The results of this study show that brand reputation has a significant influence on the brand loyalty of Apotek Vitka Farma brand. Brand competence has a significant influence on the reliability of Apotek Vitka Farma brand. Brand preference has a significant influence on the brand loyalty of Apotek Vitka Farma brand. Consumer's trust in the company has a significant influence on the brand loyalty Apotek Vitka Farma brand. Trust in company has dominant influence on the brand loyalty of Apotek Vitka Farma.
\end{abstract}

Keywords: brand reputation, brand competence, brand preferences, trust in the company, brand loyalty, Apotek Vitka Farma

\section{Pendahuluan}

Kemajuan sebuah bangsa dapat dilihat dari kemajuan dunia kesehatan yang ada. Setiap pemerintah sadar bahwa kesehatan adalah aspek dasar pergerakan sebuah bangsa sejajar dengan aspek pendidikan yang merupakan sendi sendi membentuk negara yang kuat dan bertujuan untuk memberikan kesejahteraan bagi seluruh warganya. Demi pencapaian tujuan mulia terebut maka setiap titik wilayah suatu negara perlu merasakan mendapatkan kemudahan dalam perolehan pengobatan dan layanan jasa kesehatan termasuk didalamnya adalah kemudahan mrendapatkan pasokan obat yang masyarakat luas inginkan dengan variasi kebutuhan masing masing. 
Sebagai salah satu sarana penunjang dalam pendisrtibusian obat obatan pada dunia kesehatan maka kehadiran apotek apotek swasta dimungkinkan Hal ini diharapkan oleh pemerintah untuk membantu sekaligus untuk mendukung ketercapaian disribusi yang merata bagi masyarakat untuk mengakses obat obatan yang mereka perlukan demi kesehatan mereka. Masyarakat yang sehat akan dapat membentuk negara yng kuat.

Salah satu dari beberapa apotek yang ada di kota Batam adalah apotek Vitka Farma. Keberadaan apotek ini sudahlah sangat tepat jika dilihat dari dinamika kota Batam yang terus berkembang dan terus bertambah jumlah penduduknya karena pertumbuhan ekonomi yang terus meningkat. Keberadaan apotek di kota ini menjadi keniscayaan bisnis yang dapat mendukung program kesehatan nasional. Ketatnya persaingan dalam dunia bisnis membuat apotek apotek yang menjual obat obatan di lini yang sama harus mencari strategi yang tepat dalam memasarkan produknya sehingga dapat mencapai dan memenuhi kebutuhan konsumenya. Pada prinsipnya minat beli terhadap suatu merek produk tertentu atau tempat tertentu diperoleh dari suatu proses belajar dan proses pemikiran yang membentuk persepsi terhadap merek atau tempat tersebut. Minat pembelian ini menciptakan suatu motivasi yang terus terekam dalam benak konsumen dan menjadi keinginan yang sangat kuat yang pada akhirnya ketika seorang konsumen harus memenuhi kebutuhannya akan mengaktualisasikan apa yang ada didalam benaknya, sehingga membentuk tahapan pola aware, intention, desire, and action dalam diri seorang konsumen.(Kotler. P, 2008)

Persaingan merek dalam diri konsumen tidak lagi terbatas pada atribut fungsional produk seperti kegunaan produk, melainkan sudah dikaitkan dengan merek yang mampu memberikan citra khusus bagi pemakainya (Madeira Pontes et al., 2019). Pada tingkat persaingan yang rendah, merek hanya sekedar membedakan antara satu produk dengan produk lainnya atau melihat merek hanya sekedar nama (just a name). Sedangkan pada tingkat persaingan yang tinggi, merek memberikan kontribusi dalam menciptakan dan menjaga daya saing sebuah produk. Merek akan dihubungkan dengan citra khusus yang mampu memberikan asosiasi tertentu dalam benak konsumen. Dalam perkembangannya, perusahaan semakin menyadari merek sebagai aset perusahaan yang paling bernilai (James, 2007)

Merek bukanlah sebuah nama, simbol, gambar atau tanda yang tidak berarti. Merek merupakan identitas sebuah produk yang dapat disajikan sebagai alat ukur apakah produk itu baik dan berkualitas, dalam menghadapi persaingan yang ketat, merek yang kuat merupakan pembeda yang jelas, bernilai dan berkesinambungan, merek menjadi ujung tombak bagi daya saing perusahaan dan sangat membantu strategi perusahaan. Konsumen akan melihat sebuah merek sebagai bagian yang paling penting dalam sebuah produk, dan merek dapat menjadi sebuah nilai tambah dalam produk tersebut (Tjiptono, 2008)

Perusahaan di masa depan akan semakin bergantung kepada merek baik pada merek produk maupun merek penjual atau distributor. Kedua hal ini bisa saling bersinergi dalam membuat nilai daya saing di mata konsumen, hal ini menyiratkan bahwa persaingan tidak cukup hanya berorientasi pada produk. Perusahaan yang melibatkan orientasi merek dalam formulasi strategi perusahaannya, maka perusahaan tersebut memiliki sumber untuk menuju keunggulan bersaing yang berkelanjutan (sustainable competitive advantage). Sebuah merek yang sudah dikenal dan kemudian neniliki asosiasi tertentu terhadap sebuah merek distributor tertentu, sehingga merek tersebut dapat dibedakan dengan merek-merek yang lain, lalu di benak konsumen merek tersebut dipersepsikan memiliki kualitas yang tinggi dan berhasil membuat 
konsumen puas serta loyal maka merek tersebut memiliki ekuitas merek yang tinggi, yang pada akhirnya dapat mengarahkan konsumen ke titik loyalitas merek atau keloyalan pada merek dan dapat mengarahkan store loyalty (Suhardi., Wibowo AE., Wasiman., 2020)

Loyalitas merek dapat dilakukan dengan menganalisis keempat dimensi dasar ekuitas kepercayaan terhadap merek, yaitu kesukaan merek, kompetensi merek, reputasi merek, kepercayaan pada perusahaan. Semakin kuat ekuitas merek suatu produk, maka akan semakin kuat pula daya tariknya bagi konsumen untuk membeli produk tersebut dan pada akhirnya akan memberikan keuntungan yang terus meningkat kepada perusahaan bahkan membawa pada loyalitas merek pada diri konsumen (Madeira Pontes et al., 2019)

Semua perusahaan ingin membangun tingkat loyalitas merek yang kuat, adanya korelasi positif antara loyalitas merek dengan keuntungan yang tinggi bagi perusahaan (Swasta dan Irawan, 2008). Penelitian ini bertujuan menganalisis pengaruh Reputasi merek, Kompetensi merek, Kesukaan merek, Kepercayaan pada perusahaan terhadap Keloyalan pada merek Apotek Vitka Farma

\section{Kajian Pustaka / Kajian teori}

Loyalitas merek. Loyalitas pelanggan terhadap merek baik merek sebuah produk atau merek toko merupakan konsep yang sangat penting khususnya pada kondisi tingkat persaingan yang sangat ketat dengan pertumbuhan yang rendah. Loyalitas merek dapat diberikan penjelasan sebagai kondisi kukuhnya pelanggan terhadap suatu merek yang dapat meliputi loyal kepada produk atau merek distributor atau merek tokonya, yang memungkinkan adanya keterikatan emosional sehingga pelanggan enggan berpindah kepada merek lain. Pada kondisi demikian loyalitas pada merek sangat dibutuhkan agar perusahaan dapat bertahan hidup. Di samping itu, upaya mempertahankan loyalitas merek merupakan strategi yang lebih efektif dibandingkan dengan upaya menarik pelanggan baru.

Kepercayaan terhadap merek (trust in a brand) memegang peranan yang penting dalam terciptanya loyalitas konsumen pada suatu loyalitas merek (brands) tertentu. Setidaknya ada empat faktor yang mempengaruhi kepercayaan terhadap merek. Keempat faktor ini berhubungan dengan empat entitas yang tercakup dalam hubungan antara merek dan konsumen. Adapun keempat faktor tersebut adalah reputasi merek, kompetensi merek, kesukaan merek, kepercayaan pada perusahaan (James, 2007).

Reputasi merek mengacu pada pendapat orang lain tentang bagus tidaknya dan dapat dipercaya tidaknya suatu merek. Reputasi merek dapat dikembangkan melalui iklan dan hubungan dengan masyarakat (public relationship), tetapi kemungkinan juga dapat dipengaruhi oleh kualitas dan kinerja merek (Kotler dan Kelller, 2012). Reputasi yang baik akan menguatkan kepercayaan konsumen, dari kepercayaan tersebut akam bertumbuh menjadi keloyalan kepada sebuah brand atau merek. Jika konsumen merasakan bahwa orang lain berpendapat bahwa merek tertentu memiliki reputasi yang bagus, maka konsumen tersebut dapat mempercayai merek itu untuk kemudian membelinya. Setelah berpengalaman memakai, jika ternyata merek tersebut dapat memenuhi harapan konsumen, maka dapat dinyatakan bahwa reputasi yang bagus sudah memberikan umpan balik dalam membangun kepercayaan konsumen dan pada giliranya akan menumbuhkan loyalitas konsumen (Wibowo, A.E., Silitonga., 2020).

Reputasi merek merupakan bagian ketiga dari kepercayaan pada merek yang 
harus dibangun untuk dapat mempengaruhi konsumen dalam nama besar merek sehingga dapat mempengaruhi tingkat keloyalan mereka terhadap suatu merek produk. Jika merek tidak memiliki reputasi yang baik, konsumen akan menjadi semakin ragu Jadi persepsi konsumen bahwa suatu merek memiliki reputasi yang baik sangatlah berkaitan dengan kepercayaan konsumen terhadap merek tersebut. Sehingga membangun reputasi merek yang baik akan sejalan dengan pemberian nilai kepercayaan merek yang baik.

Kompetensi merek merupakan bagian kedua dari kepercayaan pada merek yang harus dibangun untuk dapat mempengaruhi konsumen dalam mempersepsikan nilai unggul atau kompetensi suatu merek yang pada akhirnya dapat mempengaruhi tingkat keloyalan mereka terhadap suatu merek produk..Kompetensi merek, merupakan merek yang mempunyai kemampuan untuk memecahkan permasalahan yang dihadapi oleh konsumen dan memenuhi segala keperluannya.. Konsumen mungkin mengetahui kompetensi merek melalui proses hubungan langsung atau komunikasi dari mulut ke mulut yang menceritakan sebuah merek atau brands tersebut. Diyakini bahwa suatu merek mampu memecahkan permasalahannya, maka konsumen akan percaya pada merek tersebut, dan menyimpanya dalam benak mereka (Alfred, 2013)

Kesukaan merek merupakan bagian dari kepercayaan pada merek yang harus dibangun untuk dapat mempengaruhi konsumen dalam hal kesukaan terhadap merek yang pada akhirnya dapat mempengaruhi tingkat keloyalan mereka terhadap suatu merek produk. Kesukaan merek menunjukkan kesukaan yang dimiliki oleh suatu kelompok terhadap sesuatu karena ada aspek manfaat yang dipenuhinya. Bagi konsumen, untuk membuka hubungannya dengan suatu merek, maka konsumen tersebut harus menyukai dulu merek tersebut yang didapat dari pengalaman masa lalunya.

Di pasar konsumen, jika seorang konsumen menyukai suatu jenis merek (yaitu suatu merek yang menurutnya sesuai dan menarik), kemungkinan konsumen akan lebih mempercayai merek tersebut. Secara formal dapat dinyatakan simpati konsumen terhadap suatu merek baik berupa merek produk maupun store atau tempat atau tokonya sangat berhubungan dengan kepercayaan konsumen terhadap merek atau store tersebut (Istikhamah \& Yuliati, 2016)

Kepercayaan pada perusahaan merujuk pada pengetahuan atau pemahaman konsumen tentang perusahaan yang ada di balik suatu merek. Karakteristik perusahaan yang diperkirakan dapat mempengaruhi kepercayaan konsumen terhadap perusahaan (kepercayaan pada perusahaan) adalah reputasi perusahaan (company reputations) dan integritas perusahaan yang dirasakan (company integrity) oleh konsumen. Kepercayaan pada perusahaan adalah rasa percaya bahwa perusahaan itu bagus, memiliki bonafiditas yang tinggi dan mempunyai kemampuan untuk memberikan produk yang berkualitas. Ketika kesatuan komponen tersebut dipercaya, maka kesatuan-kesatuan yang lebih kecil juga cenderung dipercaya hal ini dapat memberikan dampak tingkat kepercayaan terhadap perusahan meningkat dan hal ini akan memberikan efek yang positif bagi perjalanan loyalitas konsumen pada merek. Dilihat dari segi perusahaan dan produk yang dikeluarkannya, perusahaan yang lebih besar merupakan kesatuan yang lebih besar. Jadi konsumen yang menempatkan atau menaruh kepercayaan pada sebuah perusahaan, kemungkinan akan mempercayai merek yang dipromosika atau dijualnya (Kelley et al., 2020) 


\section{Kerangka Penelitian}

Model penelitian yang digunakan dalam penelitian ini terdiri komponen kesukaan merek, kompetensi merek, reputasi merek, kepercayaan pada perusahaan terhadap keloyalan pada merek Apotek Vitka Farma.

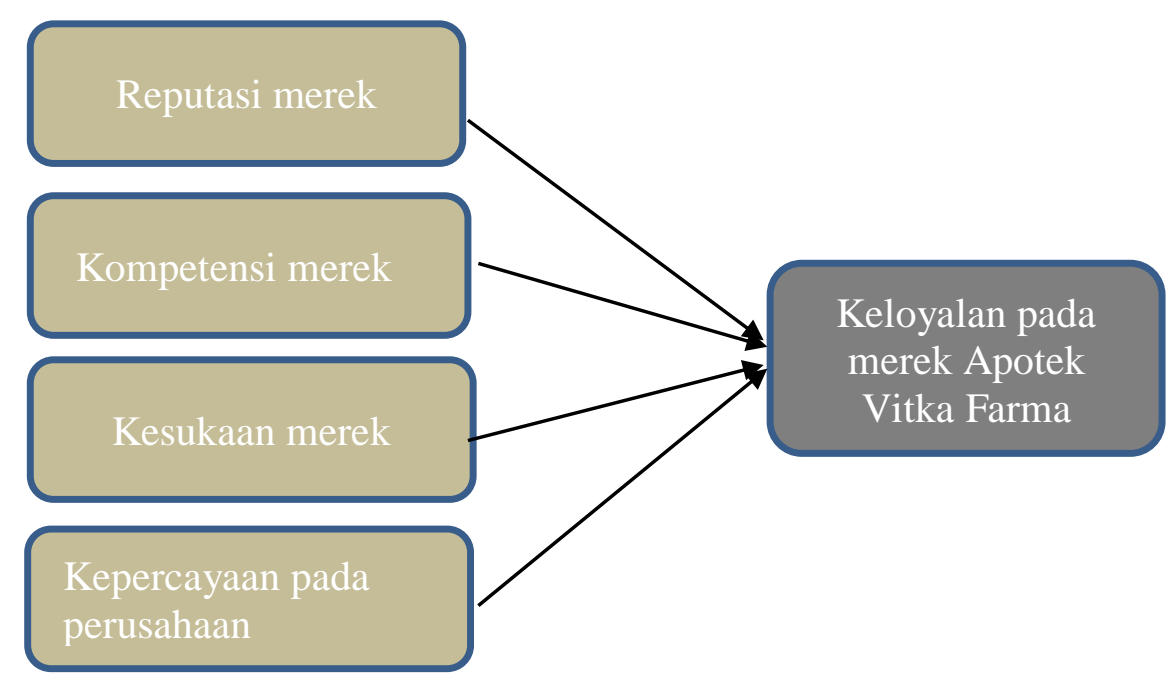

Gambar 1. Kerangka Penelitian

\section{Hipotesis}

$\mathrm{H}_{1}$ : Reputasi merek memiliki pengaruh yang signifikan terhadap keloyalan pada merek Apotek Vitka Farma

$\mathrm{H}_{2}$ : Kompetensi merek memiliki pengaruh yang signifikan terhadap keloyalan pada merek Apotek Vitka Farma

$\mathrm{H}_{3}$ : Kesukaan merek memiliki pengaruh yang signifikan terhadap keloyalan pada merek Apotek Vitka Farma

$\mathrm{H}_{4}$ : Kepercayaan pada perusahaan memiliki pengaruh yang signifikan terhadap keloyalan pada merek Apotek Vitka Farma

\section{Metode Penelitian}

Penelitian ini merupakan penelitian causal yang menghubungkan pengaruh variabel indpenden terhadap variabel dependen dengan menggunakan instrumen penyebaran angket atau survey. Variabel independen dalam penelitian ini terdiri dari reputasi merek, kompetensi merek, kesukaan merek, kepercayaan pada perusahaan sedangkan variabel dependen dalam penelitian ini adalah keloyalan pada merek.

Populasi dalam penelitian ini adalah seluruh konsumen atau masyarakat yang telah dan pernah menikmati layanan jasa pembelian obat di Apotek Vitka Farma di kota Batam. Sedangkan sampel yang diambil dalam penelitian ini menggunakan metode purposive sampling yaitu mengambil besarnya jumlah sampel dengan syarat syarat tertentu (Sugiyono, 2009). Adapun syarat syarat tertentu dalam pengambilan sampel dimaksud adalah :

1. Responden pernah melakukan transaksi (pembelian obat) dengan Apotek Vitka Farma minimal 3 kali dalam kurun waktu 5 tahun

2. Responden berusia minimal 19 tahun

3. Responden tinggal di kota Batam. 
4. Responden melakukan pembelian mandiri untuk dirinya sendiri, maupun untuk orang lain.

Sedangkan jumlah responden yang akan digunakan sebagai sampel pada penelitian ini akan diperoleh dengan menggunakan rumus populasi tidak diketahui dengan rumus sebagai (Aaker) berikut:

$$
\begin{aligned}
& \mathrm{n}=\left[\begin{array}{c}
\mathrm{Z}_{\alpha / 2} \cdot \sigma \\
--------- \\
\mathrm{e}
\end{array}\right]^{2} \\
& \text { Sumber: Wibisono (2014) }
\end{aligned}
$$

Keterangan:

$$
\begin{array}{lll}
\eta & = & \text { Jumlah elemen/anggota sampel } \\
\mathrm{Z}_{\alpha / 2} & = & \text { Nilai tabel } \mathrm{Z}=0.05 \\
\sigma & = & \text { Standard deviasi populasi } \\
\mathrm{e} & = & \text { Error level (tingkat kesalahan) }
\end{array}
$$

$$
\mathrm{n}=\left[\begin{array}{c}
0,025.2 \\
------- \\
0,05
\end{array}\right]^{2}
$$

Dari hasil perhitungan dengan populasi yang tidak diketahui, diperoleh sampel yang layak diambil minimal sebanyak 100 responden, dalam penelitian ini telah diperoleh jumlah sampel sebanyak, 120 responden

Data yang telah diperoleh selanjutnya akan dianalisis menggunakan regresi linear berganda, dengan terlebih dahulu melalui tahapan syarat uji penggunaan regresi linear berganda yaitu uji asumsi klasik regresi yang terdiri dari uji normalitas, heteroskedastisitas, dan uji multikolinearitas (Wibowo A.E \& Wulandari Y, 2020). Dengan tahapan awal adanya pengujian validitas dan reliabilitas terlebih dahulu

\begin{tabular}{|c|c|}
\hline Deskripsi & Keterangan \\
\hline Usia & Jumlah (\%) \\
\hline 19 sampai dengan 29 tahun & $44(36.7)$ \\
\hline 30 sampai dengan 39 tahun & $25(20.8)$ \\
\hline Lebih dari 39 tahun & $51(42.5)$ \\
\hline jenis kelamin & jumlah \\
\hline perempuan & $48(40.0)$ \\
\hline laki laki & $72(60.0)$ \\
\hline Status & jumlah \\
\hline belum menikah & $16(13.3)$ \\
\hline
\end{tabular}
terhadap instrumen yang digunakan. Langkah akhir dari semua uji ini adalah pegujian terhadap hipotesis yang diajukan dengan menggunakan hasil dari koefisien determinasi, .uji regresi linear berganda dan uji t (Ghozali, 2013a).

\section{Hasil dan Pembahasan}

Tabel 1. Deskripsi Responden 


\begin{tabular}{|c|c|}
\hline Menikah & $104(86.7)$ \\
\hline Penghasilan & jumlah \\
\hline kurang dari Rp.5000.000 & $25(20.8)$ \\
\hline Rp.5.100.000 sampai dengan Rp.7.500.000 & $15(12.5)$ \\
\hline Rp.7.600.000 sampai dengan Rp. 10.000 .000 & $42(35.0)$ \\
\hline Rp.10.100.000 sampai dengan Rp.12.500.000 & $24(20.0)$ \\
\hline Lebih dari Rp.12.600.000 & $14(11.7)$ \\
\hline
\end{tabular}

Sumber : Olah data SPSS (2021)

Deskripsi data responden dapat dirincikan sebagai berikut; pada kelompok respoden berdasarkan usia terbagi menjadi 3 kelompok yaitu usia 19 sampai dengan 29 tahun ada 44 responden atau 36,7\%, usia 30 sampai dengan 39 tahun ada 35 responden atau $20.8 \%$, usia lebih dari 39 tahun ada 51 responden atau $42.5 \%$. Sedangkan deskripsi responden berdasarkan jenis kelamin terdapat perempuan berjumlah 48 responden atau $40.0 \%$, laki laki berjumlah 72 responden atau $60.0 \%$. Sementara deskripsi responden berdasarkan status terdapat responden belum menikah berjumlah 16 responden atau $13.3 \%$, dan menikah berjumlah 104 responden atau 86.7\%. Dan deskripsi responden berdasarkan tingkat penghasilan terdapat responden berpenghasilan kurang dari Rp.5000.000,- berjumlah 25 responden atau $20.8 \%$, berpenghasilan Rp5.100.000 sampai dengan Rp7.500.000,- berjumlah 15 responden atau $12.5 \%$, berpenghasilan $\mathrm{Rp} 7.600 .000$ sampai dengan Rp.10.000.000,- berjumlah 42 responden atau $35.0 \%$, berpenghasilan Rp10.100.000,- sampai dengan Rp. 12.500.000,- berjumlah 24 responden atau $20.0 \%$, dan responden yang memiliki penghasilan lebih dari Rp.12.600.000,- berjumlah 14 responden atau $11.7 \%$.

Tabel 2. Hasil Uji Normalitas

\begin{tabular}{llc}
\hline \multicolumn{3}{c}{ One-Sample Kolmogorov-Smirnov Test } \\
\hline $\mathrm{N}$ & \multicolumn{1}{c}{ Standardized Residual } \\
\hline Normal Parameters ${ }^{\mathrm{a}, \mathrm{o}}$ & Mean & 120 \\
\cline { 2 - 3 } & Std. Deviation & .0000000 \\
\hline Most Extreme & Absolute & .98304962 \\
\cline { 2 - 3 } Differences & Positive & .103 \\
\cline { 2 - 3 } & Negative & .103 \\
\hline Kolmogorov-Smirnov Z & &. .089 \\
\hline Asymp. Sig. (2-tailed) & 1.129 \\
\hline a. Test distribution is Normal. & .156 \\
\hline b. Calculated from data. & \\
\hline \multicolumn{2}{l}{ Sumber : Olah data SPSS (2021) } \\
\hline
\end{tabular}

Sumber : Olah data SPSS (2021)

Dari hasil pengujian data di atas menunjukan bahwa data memiliki pola data berdistibusi normal. Kenormalan distibusi data ditunjukan dari nilai hasil uji dengan tingkat signfikansi sebesar 0.156. Data penelitian memiliki nilai lebih besar dari 0.05 dapat disimpulkan data tersebut berdistribusi normal (Ghozali, 2013) 
Tabel 3.Uji Heteroskedastisitas

\begin{tabular}{ccc}
\hline Uji & Variabel & Signifkansi \\
\hline \multirow{3}{*}{ Spearman's rho } & reputasi merek & 0.068 \\
\cline { 2 - 3 } & kompetensi merek & 0.257 \\
\cline { 2 - 3 } & $\begin{array}{c}\text { kesukaan merek } \\
\text { kepercayaan pada } \\
\text { perusahaan }\end{array}$ & 0.837 \\
\hline
\end{tabular}

Sumber : Olah data SPSS (2021)

Dari hasil pengujian data di atas menunjukan bahwa masing masing variabel memiliki nilai signfikansi sebesar 0.068 untuk variabel reputasi merek, 0.257 untuk variabel kompetensi merek, 0.837 untuk variabel kesukaan merek, dan 0.927 untuk variabel kepercayaan pada perusahaan.

Tabel 4. Uji Multikolinearitas

\begin{tabular}{ccc}
\hline Variabel & Tolerance & VIF \\
\hline reputasi merek & 0.608 & 1.644 \\
\hline kompetensi merek & 0.440 & 2.271 \\
\hline kesukaan merek & 0.281 & 3.555 \\
\hline $\begin{array}{c}\text { kepercayaan pada } \\
\text { perusahaan }\end{array}$ & 0.271 & 3.692 \\
\hline
\end{tabular}

Sumber : Olah data SPSS (2021)

Dari hasil pengujian data di atas menunjukan bahwa masing masing variabel memiliki nilai tolerance sebesar 0.608 untuk variabel reputasi merek, 0.440 untuk variabel kompetensi merek, 0.281 untuk variabel kesukaan merek, dan 0.271 untuk variabel kepercayaan pada perusahaan. Semua nilai ini berada pada rentang nilai di atas 0.1. Sedangkan nilai Variance Inflation Factor (VIF) masing masing sebesar 1,644 untuk variabel reputasi merek, 2.271 untuk variabel kompetensi merek, 3.555 untuk variabel kesukaan merek, dan 3.692 untuk variabel kepercayaan pada perusahaan. Nilai tersebut berada di bawah 10, maka dapat disimpulkan data tidak terjadi gejala multikolinaritas (Wibowo, 2012)

Tabel 5. Hasil Analisis Regresi Berganda

\begin{tabular}{llccccc}
\hline Model & \multicolumn{2}{c}{$\begin{array}{c}\text { Unstandardized } \\
\text { Coefficients }\end{array}$} & $\begin{array}{c}\text { Standardized } \\
\text { Coefficients }\end{array}$ & t & Sig. \\
\cline { 3 - 6 } & $\mathrm{B}$ & Std. Error & Beta & & \\
\hline $\mathbf{1}$ &,- 414 &, 127 & & $-3,251$ &, 002 \\
\cline { 2 - 6 } & (Constant) &, 140 &, 035 &, 116 & 3,972 &, 000 \\
\hline brand_reputation &, 167 &, 041 &, 140 & 4,064 &, 000 \\
\hline brand_competence &, 235 &, 053 &, 191 & 4,435 &, 000 \\
\hline brand_liking &, 586 &, 041 &, 623 & 14,202 &, 000
\end{tabular}

Sumber : Olah data SPSS (2021)

Dari hasil uji di atas maka dapat dirumuskan besarnya hasil nilai prediktif regresi sebagai berikut $\mathrm{Y}=-0.414+0.140 \mathrm{x}_{1}+0.167 \mathrm{x}_{2}+0.235 \mathrm{x}_{3}+0.586 \mathrm{x}_{4}$. Nilai tersebut dapat dijelaskan sebagai berikut :

Konstanta yang bernilai -0.414 memiliki pengertian bahwa jika pengaruh variabel reputasi merek, kompetensi merek, kesukaan merek dan kepercayaan pada 
perusahaan tidak berubah ataup nol maka nilai keloyalan pada merek Apotek Vitka Farma bernilai -0.414 point. Selanjutnya jika variabel reputasi merek berubah 1 point atau 1 satuan maka keloyalan pada merek Apotek Vitka Farma akan berubah sebesar 0.140 dengan asumsi variabel lain tidak berubah atau tetap. Dan jika variabel kompetensi merek berubah 1 point atau 1 satuan maka keloyalan pada merek Apotek Vitka Farma akan berubah sebesar 0.167 dengan asumsi variabel lain tidak berubah atau tetap. Sedangkan jika variabel kesukaan merek berubah 1 point atau 1 satuan maka keloyalan pada merek Apotek Vitka Farma akan berubah sebesar 0.235 dengan asumsi variabel lain tidak berubah atau tetap. Sedangkan jika variabel kepercayaan pada perusahaan berubah 1 point atau 1 satuan maka keloyalan pada merek Apotek Vitka Farma akan berubah sebesar 0.586 dengan asumsi variabel lain tidak berubah atau tetap.

Tabel 6. Hasil Uji Koefisien Determinasi

\begin{tabular}{lcccc}
\hline \multicolumn{4}{c}{ Model Summary } \\
\hline Model & $\mathrm{R}$ & R Square & Adjusted R Square & Std. Error of the Estimate \\
\hline 1 & $.970^{\mathrm{a}}$ & .940 & .938 & .17132 \\
\hline
\end{tabular}

Sumber : Olah data SPSS (2021)

Dari hasil pengujian data di atas nilai $\mathrm{R}^{2}$ Koefisien Determinasi (KD) sebesar 0.940. Hal ini menunjukan bahwa proporsi sumbangan perubahan nilai keloyalan pada merek Apotek Vitka Farma dipengaruhi oleh variabel reputasi merek, kompetensi merek, kesukaan merek dan kepercayaan pada perusahaan sebesar 0.940 atau $94 . \%$ dan sebesar 0.06 atau $6 \%$ sisanya dipengaruhi oleh variabel yang tidak dihadirkan dalam penelitian ini.

Tabel 7. Hasil Uji Hipotesis

\begin{tabular}{|c|c|c|c|c|}
\hline \multicolumn{2}{|c|}{ Model } & $\begin{array}{c}\text { Standardized } \\
\text { Coefficients } \\
\text { Beta }\end{array}$ & $\mathbf{t}$ & Sig. \\
\hline 1 & (Constant) & & $-3,251$ & ,002 \\
\hline & brand_reputation & ,116 & 3,972 & ,000 \\
\hline & brand_competence & , 140 & 4,064 & ,000 \\
\hline & brand_liking & ,191 & 4,435 & ,000 \\
\hline & trust_in_the_company & ,623 & 14,202 & ,000 \\
\hline
\end{tabular}

Sumber : Olah data SPSS (2021)

Dari hasil uji penelitian menunjukan bahwa

Reputasi merek memniliki pengaruh terhadap keloyalan pada merek Apotek Vitka Farma, hal ini dinyatakan dari hasil uji yang menunjukan nilai signfikansi variabel reputasi merek sebesar 0.000 lebih kecil dari 0.05. Keberartian ini memperlihatkan bahwa reputasi merek Apotek Vitka Farma yang ada pada benak konsumen dianggap memiliki positioning yng baik dan berada pada area mudah diingat dan selalu ada dalam pikiran konsumen ketika mereka memiliki asossiasi keadaan, kejadian atau berhubungan dengan dunia kesehatan dan obat. Konsumen menganggap Apotek Vitka Farma memiliki kesanggpuan memenuhi keperluan dan kebutuhan konsumen ketika mereka memiliki suatu situasi yang berhubungan dengan aspek kesehatan. Keadaan ini dapat mengarah pada perjalanan loyal kepada sebuah 
merek. Merek yang memiliki loyalitas yang tinggi di mata konsumen dapat dibangun melalui keterlibatan yang tinggi merek tersebut dengan konusmennya (Kotler, 2016).

Kompetensi merek memniliki pengaruh terhadap keloyalan pada merek Apotek Vitka Farma, hal ini dinyatakan dari hasil uji yang menunjukan nilai signfikansi variabel kompetensi merek sebesar 0.000 lebih kecil dari 0.05. Hal ini memperlihatkan bahwa kompetensi merek Apotek Vitka Farma berada pada positioning yang baik atau top of mind. Adapun kompetensi merek ini dapat dilihat dari perasaan yakinnya konsumen terhadap kompetensi atau kemanjuran dari persediaan barang yang dijual oleh Apotek Vitka Farma yang dirasakan oleh konsumen, telah memenuhi aspek yang diharapkan dan memenuhi tingkat kepuasan yang dipersepsikan oleh konsumenya. Apotek Vitka Farma telah dipersepsikan menyediakan dan memberikan prodik produk yang dapat memenuhi kebutuhan konsumen bahkan dalam beberapa aspek dianggap memiliki nilai lebih dari harapan konsumen. Kinerja kompetensi merek seperti ini jika terus dipertahankan dapat menggeser persepsi konsumen untuk menjadi loyalist bukan saja kepada produk yang dijual namun juga kepada merek tokonya, store loyalty (Kotler dan Kelller, 2012).

Kesukaan merek memiliki pengaruh terhadap keloyalan pada merek Apotek Vitka Farma, hal ini dinyatakan dari hasil uji yang menunjukan nilai signifkansi variabel kesukaan merek sebesar 0.000 lebih kecil 0.05. Keberartian ini menunjukan bahwa kesukaan merek Apotek Vitka Farma dipersepsikan sama seperti halnya reputasi merek dan kompetensi merek berada pada puncuk tertinggi pada proses positioning di mata konsumen dan menjadi top of mind yang dibentuk dari proses liking atau kesukaan konsumen terhadap merek Apotek Vitka Farma. Ini menunjukan bahwa tahapan konsumen terhadap proses aware, intention, desire dan action konsumen terhadap keberadaan Apotek Vitka Farma sebagai penyedia beragam obat ataupun produk produk kesehatan dipersepsikan oleh konsumen dalam kategori disukai.

Kepercayaan pada perusahaan memiliki pengaruh terhadap keloyalan pada merek Apotek Vitka Farma, hal ini dinyatakan dari hasil uji yang menunjukan nilai signifkansi variabel kesukaan merek sebesar 0.000 lebih kecil 0.05. Hal ini menunjukan bahwa konsumen memiliki cukup alasan loyal kepada nama merek Apotek Vitka Farma yang didasarkan pada kenytaan bahwa mereka atau konsumen ini memiliki dasar yang kuat untuk loyal yang dibangun dari trust atau percaya terhadap produk dan layanan jasa yang diberikan oleh Apotek Vitka Farma. Rasa percaya ini dibangun oleh konsumen dari perjalanan masa lalu masing masing konsumen ketika berhubungan Apotek Vitka Farma. Perjalanan pengalaman yang baik akan memberikan dampak positif kepada seperangkat bangunan persepsi jasa layanan yang diterima konsumen tersebut setiap harinya (Rangkuti, 2009).

Demikan juga pengalaman yang buruk akan dapat mengikis rasa percaya dan pada akhirnya dapat menjadi faktor yang menghambat konsumen untuk lebih terlibat bahkan menolak untuk berhubungan kembali. Sebaliknya bangunan kesan atau persepsi positif yang berhasil masuk dalam benak konsumen dapat mempengaruhi konsumen untuk melakukan repeating buying dan pada akhirnya dapat membentuk loyalitas konsumen terhadap produk dan jasa layanan Apotek Vitka Farma.

Melihat dari hasil tabel uji di atas dapat dianalisis dengan jelas bahwa dari keempat variabel yang dihadirkan dalam penelitian ini yang terdiri dari; reputasi merek, kompetensi merek, kesukaan merek dan kepercayaan pada perusahaan menunjukan bahwa variabel yang memiliki sumbangan pengaruh yang paling dominan adalah variabel kepercayaan pada perusahaan hal ini dibuktikan dengan nilai 
Standardized Coefficients Beta sebesar 0.623 yang merupakan nilai paling besar dari nilai koefisen masing masing variabel penelitian yang digunakan.

\section{Simpulan dan Saran}

Simpulan dari penelitian ini adalah reputasi merek memiliki pengaruh signfikan terhadap keloyalan pada merek Apotek Vitka Farma. Kompetensi merek memiliki pengaruh signifkan terhadap keloyalan pada merek Apotek Vitka Farma. Kesukaan merek memiliki pengaruh signfikan terhadap keloyalan pada merek Apotek Vitka Farma, dan kepercayaan pada perusahaan memiliki pengaruh signfikan terhadap keloyalan pada merek Apotek Vitka Farma. Aspek lain dari penelitian yang ditemukan adalah variabel kepercayaan pada perusahaana memiliki pengaruh paling dominan terhadap keloyalan pada merek Apotek Vitka Farma pada diri konsumen.

Hasil dari temuan ini dapat diberikan saran bagi manajer pemasaran unit atau divisi layanan kesehatan Apotek Vitka Farma khususnya agar terus mempertahankan dan mengupayakan ke empat aspek variabel di atas yang membangun brand loyalty terhadap merek Apotek Vitka Farma untuk selalu berada pada top of mind seperti saat ini, mengingat persaingan produk dan layanan jasa apotek mulai terus berkembang dan munculnya pesaing baru. Pihak manajemen perlu melakukan differinsiasi layanan baru yang inovatif kedepanya seperti memberikan layanan antar dan model pembelian dan pemesanan via online, dengan demikian efisiensi dan kecepatan layanan dapat semakin baik, dan memberi tambahan atribut yang diberi kesan positif yang dapat menjadi daya perekat top of mund pada benak konsumen atau pelanggan.

\section{Daftar Pustaka}

Alfred, O. (2013). Influences of Price And Quality On Consumer Purchase Of Mobile Phone In The Kumasi Metropolis In Ghana A Comparative Study. 5(1), 179.

Ghozali, I. (2013a). Analisis Multivariate dengan Program SPSS 21. Penerbit BPFE, Undip. 98.

Ghozali, I. (2013b). Aplikasi Analisis Multivariate dengan Program IBM SPSS 21 Update PLS Regresi (7th ed.). Undip.

Istikhamah, I.-, \& Yuliati, L. N. (2016). The Influence of Motivation, Needs, and Access to Information on Family Financial Planning in Life Insurance Purchasing. Journal of Consumer Sciences, 1(2), 28. https://doi.org/10.29244/jcs.1.2.28-42

James, B. (2007). Secrets of Customer Relatuonship Management, 2007. Gramedia Jakarta.

Kelley, H. H., LeBaron, A. B., \& Hill, E. J. (2020). Family Matters: Decade Review from Journal of Family and Economic Issues. Journal of Family and Economic Issues. https://doi.org/10.1007/s10834-020-09706-8

Kotler. P. (2008). Marketing Management 6th Edition, Englewood Cliffs, New Jersey, Prentice Hall.

Kotler dan Kelller. (2012). Marketing Management 4th Edition, Englewood Cliffs, New Jersey, Prentice Hall.

Madeira Pontes, M. D., Peñaloza, V., \& Duarte Pontes, T. L. (2019). Impact of Financial Difficulties on Consumer Behavior: Gender Differences. Innovar, 30(75), 31-41. https://doi.org/10.15446/innovar.v30n75.83237

Rangkuti, F. (2009). Strategi Riset dan Memenangkan Pasar Pemasaran Cetakan ke 12 PT. SUN Jakarta. 207.

Sugiyono. (2009). Metode Penelitian Kuantitatif dan Kualitatif. Alfabeta, Bandung. 
85.

Suhardi., Wibowo AE., Wasiman., W. (2020). Service Quality, Trust and Price on Customer Loyalty in PT Pos Indonesia Batam City. IOSRjournals.Org, 22(9).

Swasta dan Irawan. (2008). Perilaku Konsumen dalam Era Milenium, JEBI, Universitas Gadjah Mada.

Tjiptono, F. (2008). Segmenting Pasar Sasaran Potensial. Ghalia Jakarta.

Wibowo, A.E., Silitonga., F. (2020). Pengaruh Promosi dan Kualitas Pelayanan terhadap Intention to Use Jasa Transportasi PT Batam Fast Ferry di Kota Batam. Cafetaria, 1(2), 23-32.

Wibowo, A. E. (2012). Aplikasi Praktis SPSS dalam Penelitian. Penerbit, Gava Media, Yogyakarta. 37.

Wibowo A.E \& Wulandari Y. (2020). SPSS dalam Riset Layanan Jasa dan Kesehatan. Penerbit, Gava Media, Yogyakarta. 